\title{
Compatibility between Groundnut Rhizobium and Seed Dressing Fungicide
}

\author{
B.P. Jinturkar* \\ Department of Botany and Principal late K.G. Kataria College Daund, India \\ *Corresponding author
}

\begin{abstract}
A B S T R A C T
\section{Keywords \\ Rhizobium, \\ Dry weight, \\ Dry matter \\ content. \\ Article Info \\ Accepted: \\ 12 April 2017 \\ Available Online: \\ 10 May 2017}

A pot culture experiment was conducted to examine the compatibility of Rhizobium (Rhs-1) with four fungicide and there combination used for seed treatment. The combination effects of inoculation with fungicide growth and number of nodules, dry weight of nodules, dry matter parameters were studied, present investigation on two Spanish bunch varieties (JL-24 and SB- XI)
\end{abstract}

\section{Introduction}

The survival and inoculation efficiency of root nodules bacteria are highly influenced by several soil and plant factors such as, soil constitution, soil physical properties and the chemical seed treatments. Agricultural practices that discourage the frequency of the beneficial microorganism and subsequently their intensity of nodulation need to be carefully evaluated. Seed treatment with chemicals may impair microbial activity subsequently and attention towards this point has often been drawn in the rhizobia literature.

Contradictory evidences have been given on the compatibility between the rhizobia and seed dressing chemicals. The toxicity of chemicals containing mercury, copper or zinc to Rhizobium has been reported in the forties by Allington (1945) and Kernkamp (1948). However, Wankhede and Bhide (1972) did not find toxic effect on phenyl mercury acetate to Rhizobium japonicum. Mukewar and Bhide (1969) studied the effect of seed treatment with fungicides and antibiotic aureofungin, on nodulation in groundnut by Rhizobium sp. They observed that captan and aureofungin seed treatments did not have adverse effect on nodulation and dry weight of plant.

Balaraman and Prasad (1973) and Sardeshpande et al., (1973) reported that captan, ceresin and Brassical had no harmful effect on nodulation, dry matter weight and nitrogen content of groundnut when Rhizobium inoculation was done after fungicidal seed treatment. Kulkarni et al., 
(1975) treated the groundnut seeds with four fumigants viz., ethylene dibromide, ethylene dichloride, carbon tetrachloride, chloropicrin and phosphomine and one insecticides malathion. The pretreated seeds were used for inoculation and observed for nitrogen fixing traits. It revealed that all the fumigants expected an adverse effect on nodulation, nodule weight, leghamoglobin content, yield, dry matter weight and nitrogen content. However, malathion did not show any harmful effects.

\section{Materials and Methods}

To study effect of commonly used seed dressing fungicides on Rhizobium in groundnut, a pot culture experiment was conducted. The seeds of the groundnut variety SB-XI were treated with different fungicides, and then inoculated with rhizobial suspension, seeds dried in shade and sown.

Eight seeds per pot were sown and five plants per post were maintained. The plants were be terminated 60 days, after sowing and observation were recorded on nodule number, nodule dry weight and dry matter content of plant. The various fungicides used in the experiment for seed treatment are given in table 1 . The complete treatment schedule with and without fungicide is given in table 2 .

\section{Results and Discussion}

A pot culture experiment was conducted to examine the compatibility of Rhizobium (Rhs1) with four fungicide and there combination used for seed treatment. The combination effects of inoculation with fungicide growth and number of nodules, dry weight of nodules, dry matter parameters were studied

\section{Emergence}

The data on emergence count are given in table 3 . None of the fungicide applied either alone or in combination was detrimental to Rhizobium during treatment on the country the fungicide improved the emergence and plant stand significantly over no fungicidal treatment. The emergence was lowest in treatment when Rhizobium alone used. It was highest in Rhizobium + ceresn treatment and as per with Rhizobium + vitavax + Tthiram and Rhizobium + vitavax treatment. During summer season however, significance reduction in emergence count was noted only in Rhizobium + Bevistin SD, while treatments with Vitavax was included, improved the emergence markedly. Similarly Bavistin WP + Thiram seed treatment also appeared to be compatible with Rhizobium as emergence count in this treatment, was statistically superior to the treatment where Rhizobium alone was applied.

\section{Nodule number and nodule dry weight}

The result of effect of Rhizobium inoculation along with fungicides on nodules number and dry weight are tabulated in table 4 . The data indicated that Rhizobium was compatible with all the fungicides tested when the evaluations were done in terms of nodule number. The nodule number per plant did not very greatly in any of the treatments in both the season. However when dry weight of nodules were considered, it became clear that seed treatment of groundnut with a ceresn was detrimental, as it reduced the dry weight of nodules significantly over the Rhizobium alone. The effects between Rhizobium and fungicides were observed only in case of Vitavax treatments. The dry weight of nodules increased substantially in Rhizobium + Vitavax treatment, significant increase being over Rhizobium alone.

\section{Nitrogen content of nodules}

In the compatibility studied yet another parameters viz, the nitrogen content of nodules was also considered if that would be 
influenced by fungicides when applied along with Rhizobium and the data are given in table 5. It is evident from the data that, the percent nitrogen content at nodule and total $\mathrm{N}$ content of nodules per plant did not show significant difference amongst the treatments. The fungicide adversely affected the total nitrogen content of nodules per plant. Vitavax was found to be beneficial as it increased the total $\mathrm{N}$ content of nodules per plant Rhizobium alone.

Dry weight and nitrogen content of shoot combined application of fungicides and Rhizobium did not affect the dry weight of shoot data are given in table 6 .

The nitrogen content of shoot was highly influenced by the combined application of Rhizobium and fungicides, Rhizobium when applied with thiram reduced the percent Nitrogen and total Nitrogen content of shoot per plant, over Rhizobium alone, indicated an adverse effect of Thiram. Rhizobium applied with Vitavax improved the percent $\mathrm{N}$ content of shoot significantly over Rhizobium alone. Similarly the treatment with Bavistin SD also improved the percent $\mathrm{N}$ content of shoot.

Dry weight and nitrogen content of root- The effect of combined application of Rhizobium and fungicides on the dry weight and nitrogen content of root are tabulated in table 7. From data, it was evident that none of the fungicides had detrimental effect on Rhizobium inoculation in terms of dry weight of roots. It contract Vitavax applied along with Rhizobium has improved the dry weight of root significantly over Rhizobium alone. However, this was not reflected in present estimation. The fungicidal treatments such as ceresin, vitavax reduced the percent $\mathrm{N}$ and total $\mathrm{N}$ content of roots per plant.

Table.1 List of the fungicides used in the experiment on compatibility

\begin{tabular}{lll}
\hline Common Name & Chemical Name & Trade product used \\
\hline Thiram & Tetra methyl thiram sulphate & Hexathir sowp \\
Phenyl mercury acetate & Phenyl mercury acetate & Ceresin dry \\
Carbendazim (wp) & Methyl-2-benzimidazole carbonate & Bavistin 50 WP \\
Carbendazim (SP) & Methyl-2-benzimidazole carbonate & Bavistin 25 SPp \\
Carboxin & 5,6-dihydro-2-methyl-1,4-oxathin- & Vitavax 50 WP \\
& 3-carboxanilide & \\
\hline
\end{tabular}

Table.2 List treatment schedule for compatibility pot culture experiment

\begin{tabular}{lll}
\hline $\begin{array}{l}\text { Treatment } \\
\text { code }\end{array}$ & Treatment details & $\begin{array}{l}\text { Concentration } \\
\text { of fungicide }\end{array}$ \\
\hline T1 & Rhizobium inoculation only & -- \\
T2 & Thiram seed treatment followed by Rhizobium inoculation & $4 \mathrm{~g} / \mathrm{kg}$ \\
T3 & Cerasan dry seed treatment followed by Rhizobium inoculation & $3 \mathrm{~g} / \mathrm{kg}$ \\
T4 & Carbendazim SD seed treatment followed by Rhizobium inoculation & $4 \mathrm{~g} / \mathrm{kg}$ \\
T5 & $\begin{array}{l}\text { Carbandazim WP + Thiram seed treatment followed by Rhizobium } \\
2 \mathrm{~g}+2 \mathrm{~g} / \mathrm{kg}\end{array}$ \\
T6 & $\begin{array}{l}\text { Carboxin + thiram seed treatment followed by Rhizobium } \\
\text { Carboculation }\end{array}$ & $2 \mathrm{~g}+2 \mathrm{~g} / \mathrm{kg}$ \\
T7 & Carboxin seed treatment followed by Rhizobium inoculation & $4 \mathrm{~g} / \mathrm{kg}$
\end{tabular}


Table.3 Effect of combined seed application Rhizobium and fungicides on emergence of groundnut

\begin{tabular}{ll}
\hline Treatment & Number of nodules per Plant \\
\hline & \\
Rhizobium alone & 178.33 \\
Rhizobium + Thiram & 184.55 \\
Rhizobium + Ceresan & 194.33 \\
Rhizobium + Bavistin SD & 187.22 \\
Rhizobium + Bavistin + Thiram & 186.00 \\
Rhizobium + Vitavax + Thiram & 188.35 \\
Rhizobium + Vitavax & 189.00 \\
SE +- & 0.26 \\
CD at 5\% & 0.78 \\
\hline
\end{tabular}

Table.4 Effect of combined seed application Rhizobium culture and fungicides on nodule number and dry weight of nodule of groundnut

\begin{tabular}{|c|c|c|}
\hline Treatment & $\begin{array}{c}\text { Number of nodules per } \\
\text { Plant }\end{array}$ & $\begin{array}{c}\text { Dry weight of } \\
\text { nodule per plant }(\mathrm{g})\end{array}$ \\
\hline Rhizobium alone & 280.00 & 0.25 \\
\hline Rhizobium + Thiram & 240.00 & 0.21 \\
\hline Rhizobium + Ceresan & 180.00 & 0.17 \\
\hline Rhizobium + Bavistin SP & 250.20 & 0.27 \\
\hline Rhizobium + Bavistin + Thiram & 280.15 & 0.29 \\
\hline Rhizobium + Vitavax + Thiram & 220.12 & 0.27 \\
\hline Rhizobium + Vitavax & 30.00 & 0.35 \\
\hline $\mathrm{SE}+-$ & 4.71 & 0.031 \\
\hline $\mathrm{CD}$ at $5 \%$ & NS & 0.093 \\
\hline
\end{tabular}

Table.5 Effect of combined seed application Rhizobium culture and fungicides on nitrogen content of nodule of groundnut

\begin{tabular}{l|l|l}
\hline Treatment & Number of nodules per Plant & $\begin{array}{l}\text { Dry weight of nodule } \\
\text { per plant ( g) }\end{array}$ \\
\hline & & \\
Rhizobium alone & 3.85 & 9.37 \\
Rhizobium + Thiram & 3.67 & 9.00 \\
Rhizobium + Ceresan & 3.76 & 6.05 \\
Rhizobium + Bavistin SP & 4.85 & 10.80 \\
Rhizobium + Bavistin + Thiram & 4.33 & 11.50 \\
Rhizobium + Vitavax + Thiram & 3.66 & 9.55 \\
Rhizobium + Vitavax & 3.86 & 12.86 \\
SE +- & 0.02 & 0.11 \\
CD at 5\% & 0.06 & 0.33 \\
\hline
\end{tabular}


Table.6 Effect of combined seed application Rhizobium culture and fungicides on shoot dry weight and nitrogen content of groundnut

\begin{tabular}{l|l|l|l}
\hline Treatment & $\begin{array}{l}\text { Dry weight of } \\
\text { shoot per plant } \\
(\mathrm{g})\end{array}$ & $\begin{array}{l}\text { Percent N content in } \\
\text { Shoot per plant }\end{array}$ & $\begin{array}{l}\text { Total N content } \\
\text { in shoot per } \\
\text { plant (mg) }\end{array}$ \\
\hline & 5.88 & 2.24 & 113.50 \\
Rhizobium alone & 5.82 & 1.88 & 98.35 \\
Rhizobium + Thiram & 5.78 & 1.94 & 96.50 \\
Rhizobium + Ceresan & 5.83 & 2.36 & 118.80 \\
Rhizobium + Bavistin SP & 5.68 & 2.13 & 103.40 \\
Rhizobium + Bavistin + Thiram & 5.72 & 2.00 & 96.60 \\
Rhizobium + Vitavax + Thiram & 5.96 & 2.34 & 119.90 \\
Rhizobium + Vitavax & 0.05 & 0.01 & 0.6 \\
SE +- & NS & 0.03 & 1.8 \\
CD at 5\% &
\end{tabular}

Table.7 Effect of combined seed application Rhizobium culture and fungicides on dry weight and nitrogen content of root of groundnut

\begin{tabular}{l|l|l|l}
\hline Treatment & $\begin{array}{l}\text { Dry weight of root } \\
\text { per plant }(\mathrm{g})\end{array}$ & $\begin{array}{l}\text { Percent N content in } \\
\text { root per plant }\end{array}$ & $\begin{array}{l}\text { Total N content in } \\
\text { root per plant mg) }\end{array}$ \\
\hline & & & \\
Rhizobium alone & 0.35 & 1.48 & 4.86 \\
Rhizobium + Thiram & 0.41 & 1.52 & 5.88 \\
Rhizobium + Ceresan & 0.32 & 0.84 & 2.43 \\
Rhizobium + Bavistin SP & 0.35 & 1.40 & 4.59 \\
Rhizobium + Bavistin + Thiram & 0.37 & 1.48 & 5.09 \\
Rhizobium + Vitavax + Thiram & 0.39 & 1.41 & 5.35 \\
Rhizobium + Vitavax & 0.42 & 1.15 & 4.58 \\
SE +- & 0.01 & 0.01 & 0.05 \\
CD at 5\% & 0.03 & 0.03 & 0.15 \\
\hline
\end{tabular}

Table.8 Effect of combined seed application Rhizobium culture and fungicides on plant dry weight and nitrogen content of groundnut

\begin{tabular}{l|l|l}
\hline Treatment & Dry weight per Plant & $\begin{array}{l}\text { Total N content per } \\
\text { plant }\end{array}$ \\
\hline & & \\
Rhizobium alone & 6.46 & 118.18 \\
Rhizobium + Thiram & 6.45 & 111.35 \\
Rhizobium + Ceresan & 6.34 & 106.42 \\
Rhizobium + Bavistin SP & 6.48 & 128.84 \\
Rhizobium + Bavistin + Thiram & 6.32 & 118.87 \\
Rhizobium + Vitavax + Thiram & 6.23 & 110.37 \\
Rhizobium + Vitavax & 6.70 & 140.43 \\
SE +- & 0.08 & 0.64 \\
CD at 5\% & 0.25 & 1.92 \\
\hline
\end{tabular}

Figures in percentage are transformed values and statistics applied to them 
Fig.1 Graphical representation of effect of combined seed application Rhizobium and fungicides on emergence of groundnut

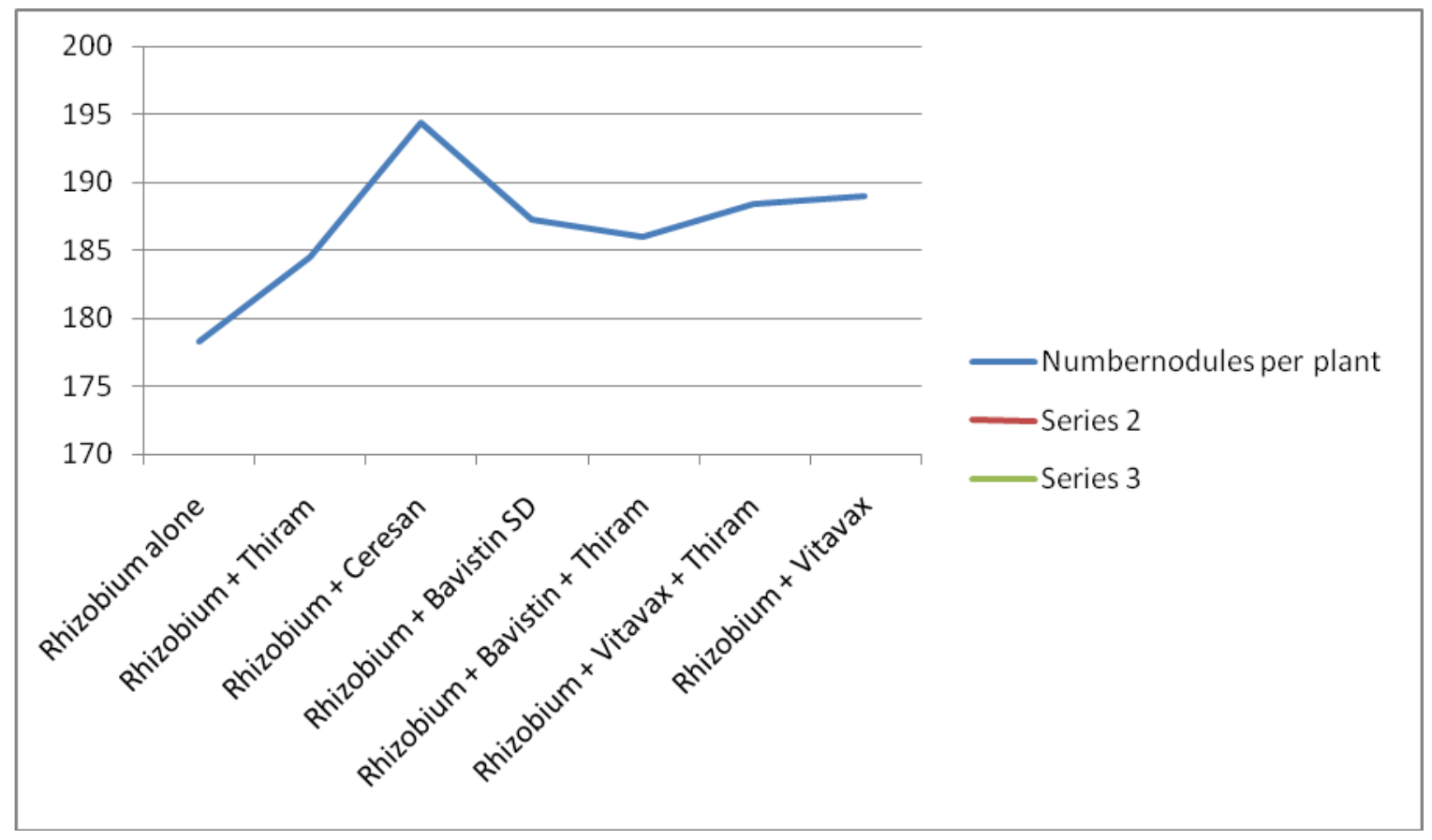

Fig 2 Graphical representation of effect of combined seed application Rhizobium culture and fungicides on nodule number and dry weight of nodule of groundnut

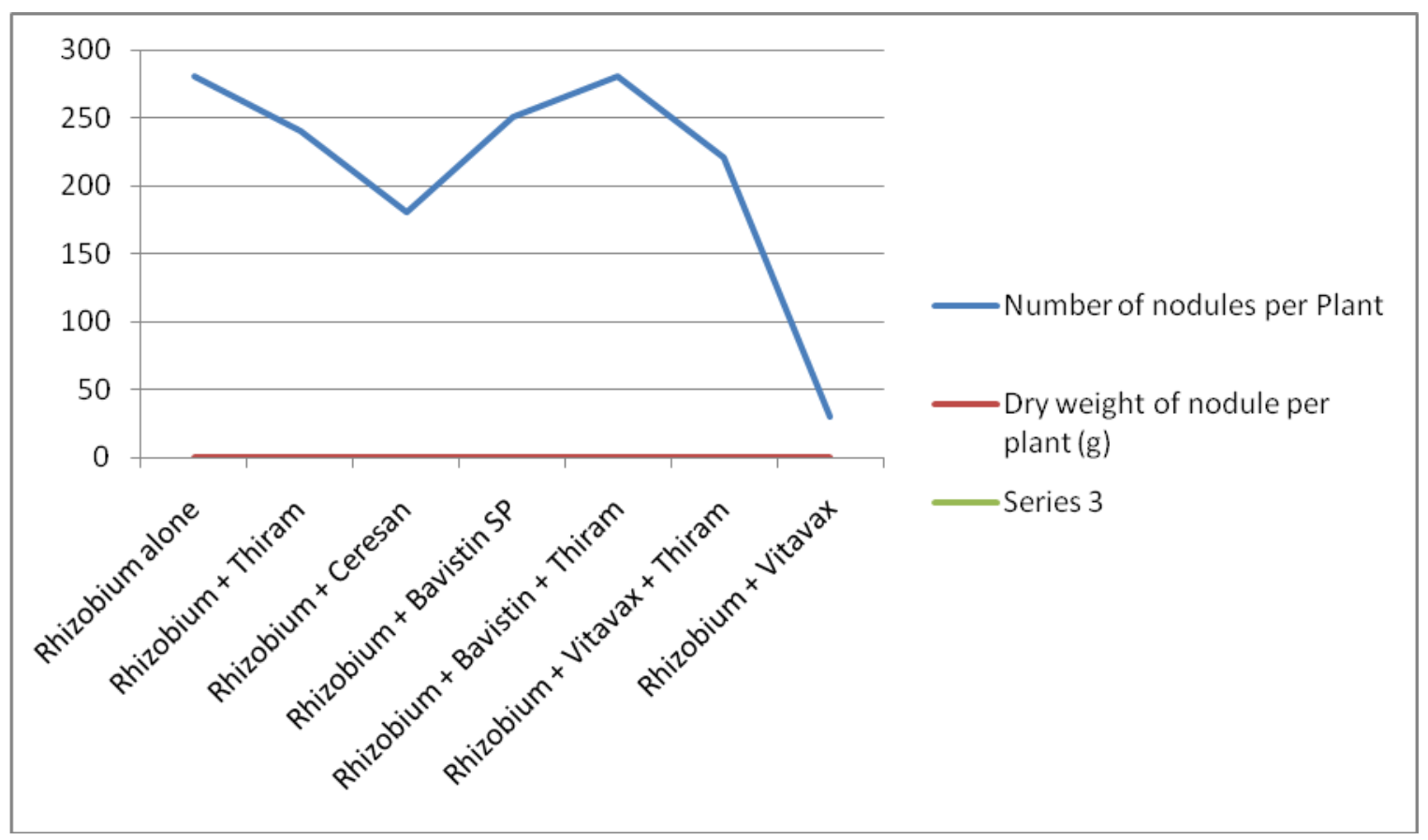


Fig.3 Graphical representation of effect of combined seed application Rhizobium culture and fungicides on nitrogen content of nodule of groundnut

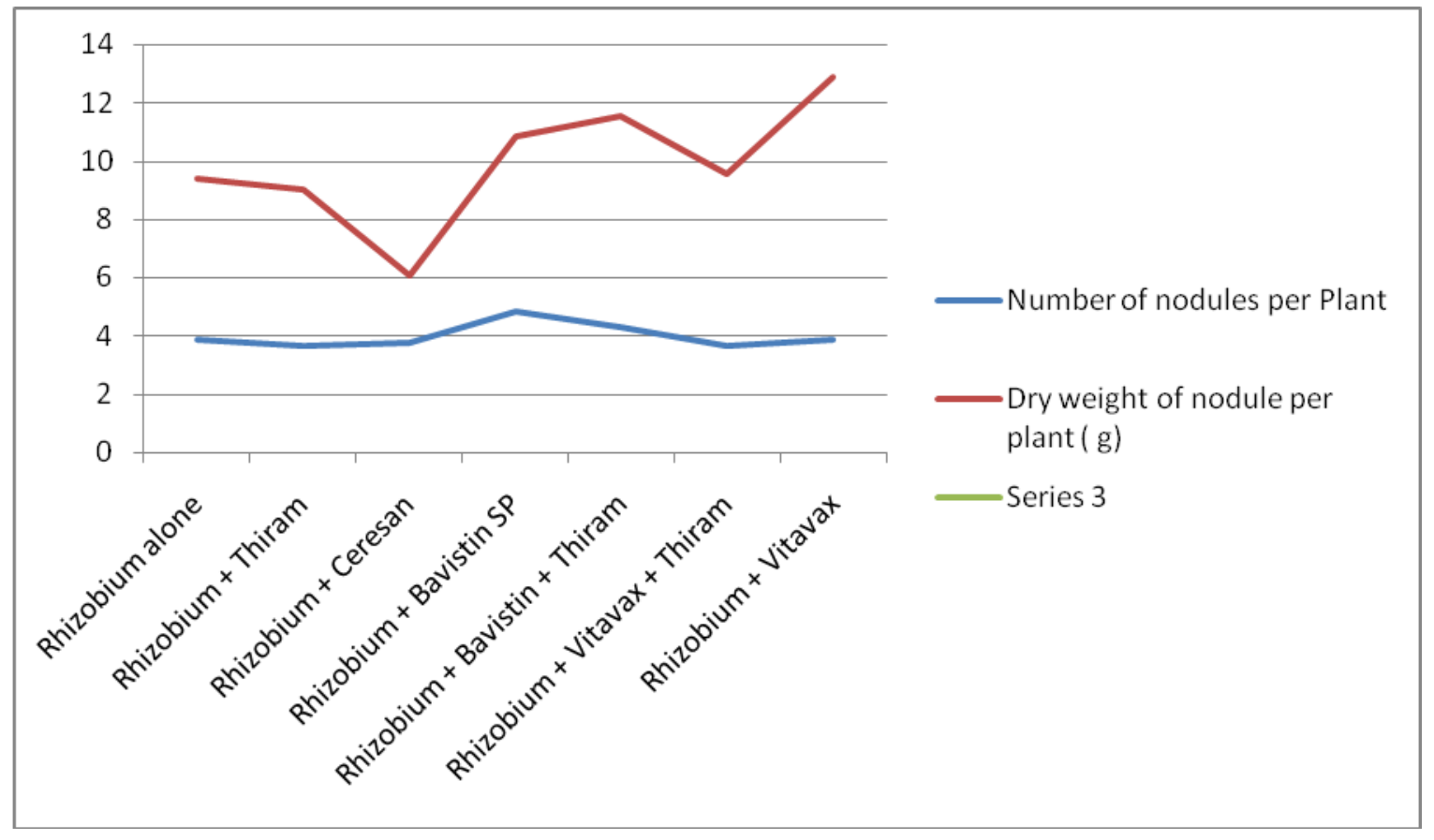

Fig.4 Graphical representation of effect of combined seed application Rhizobium culture and fungicides on shoot dry weight and nitrogen content of groundnut

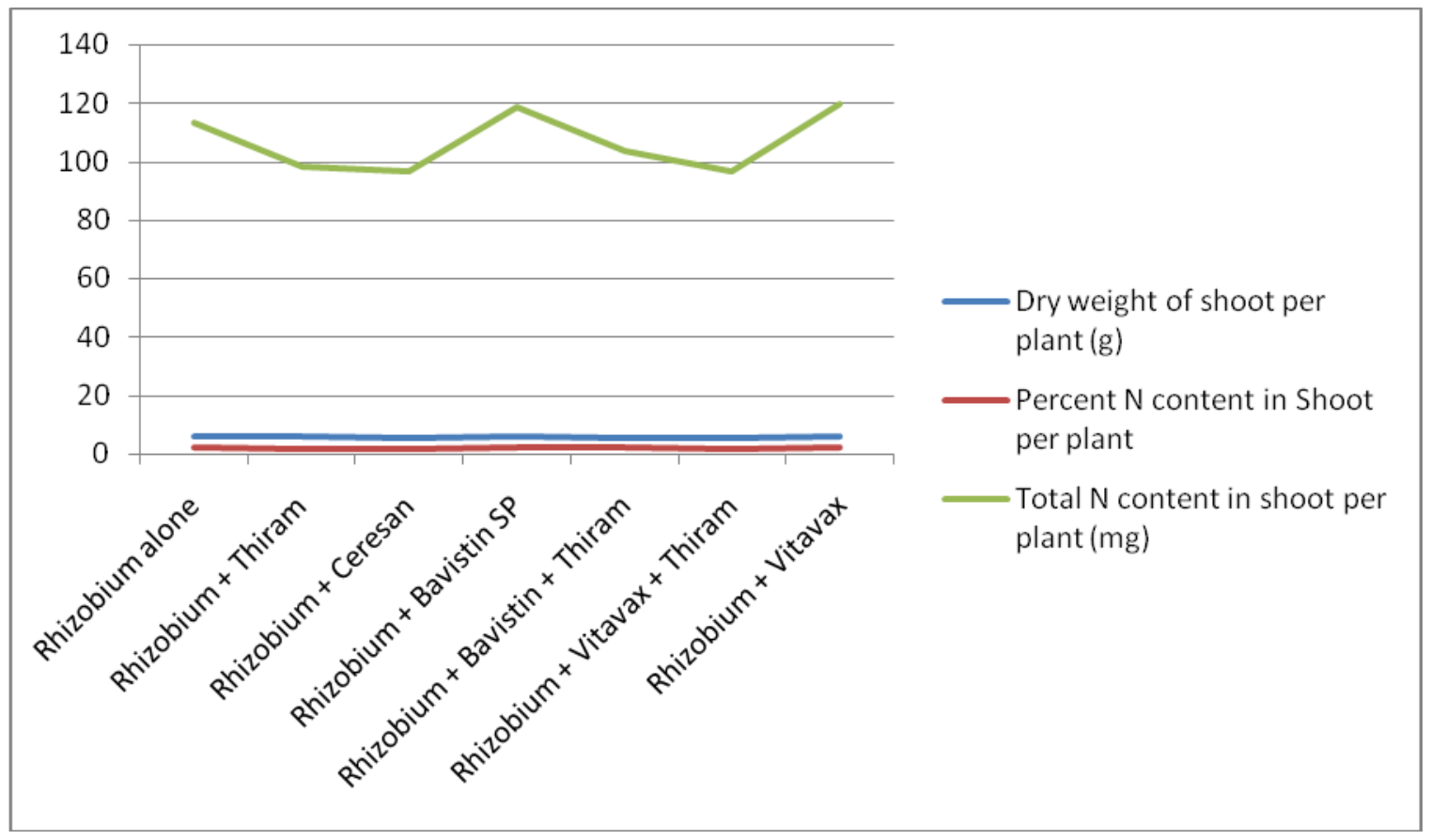


Fig.5 Graphical representation of effect of combined seed application Rhizobium culture and fungicides on dry weight and nitrogen content of root of groundnut

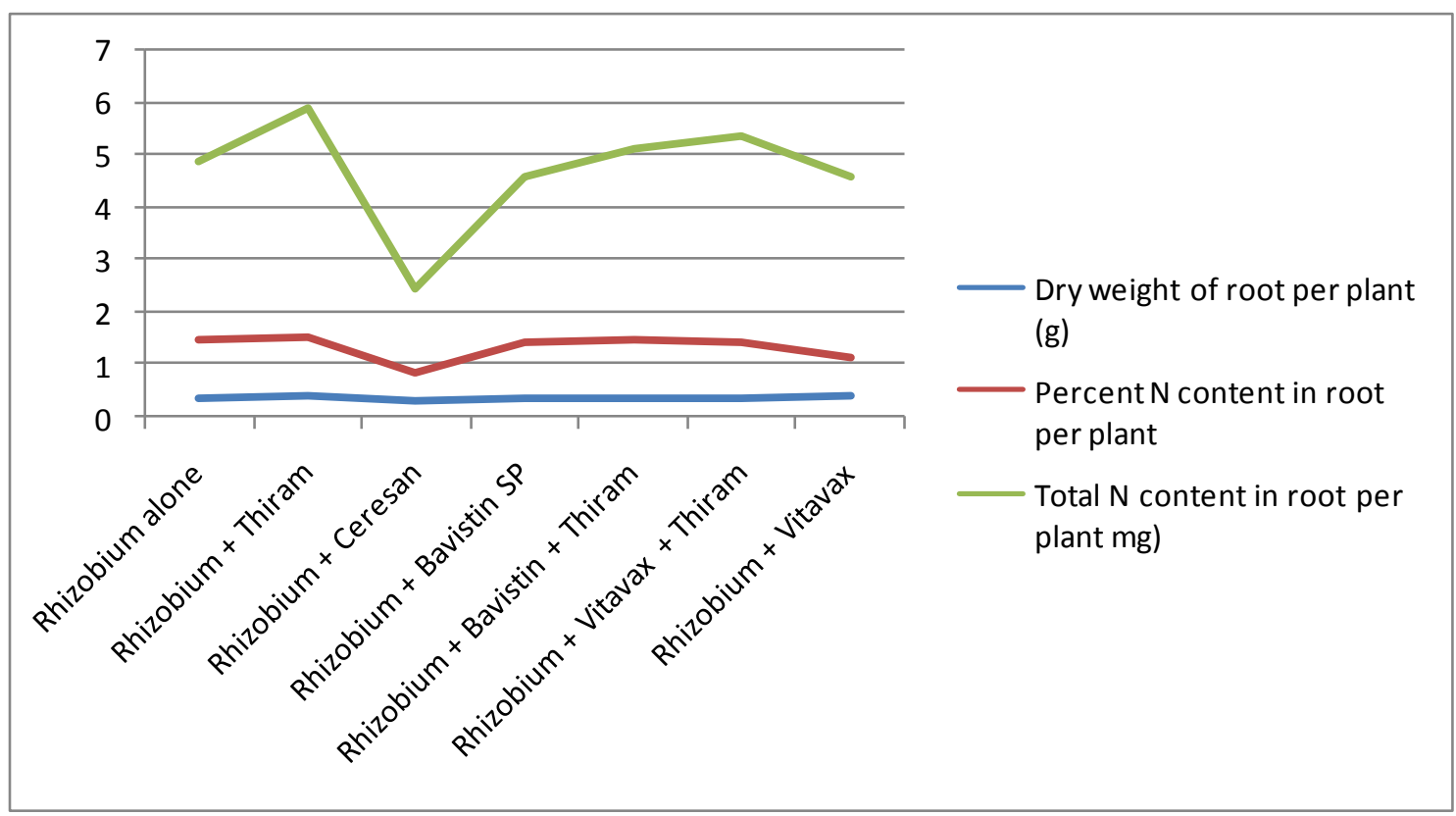

Fig.6 Graphical representation of effect of combined seed application Rhizobium culture and fungicides on plant dry weight and nitrogen content of groundnut

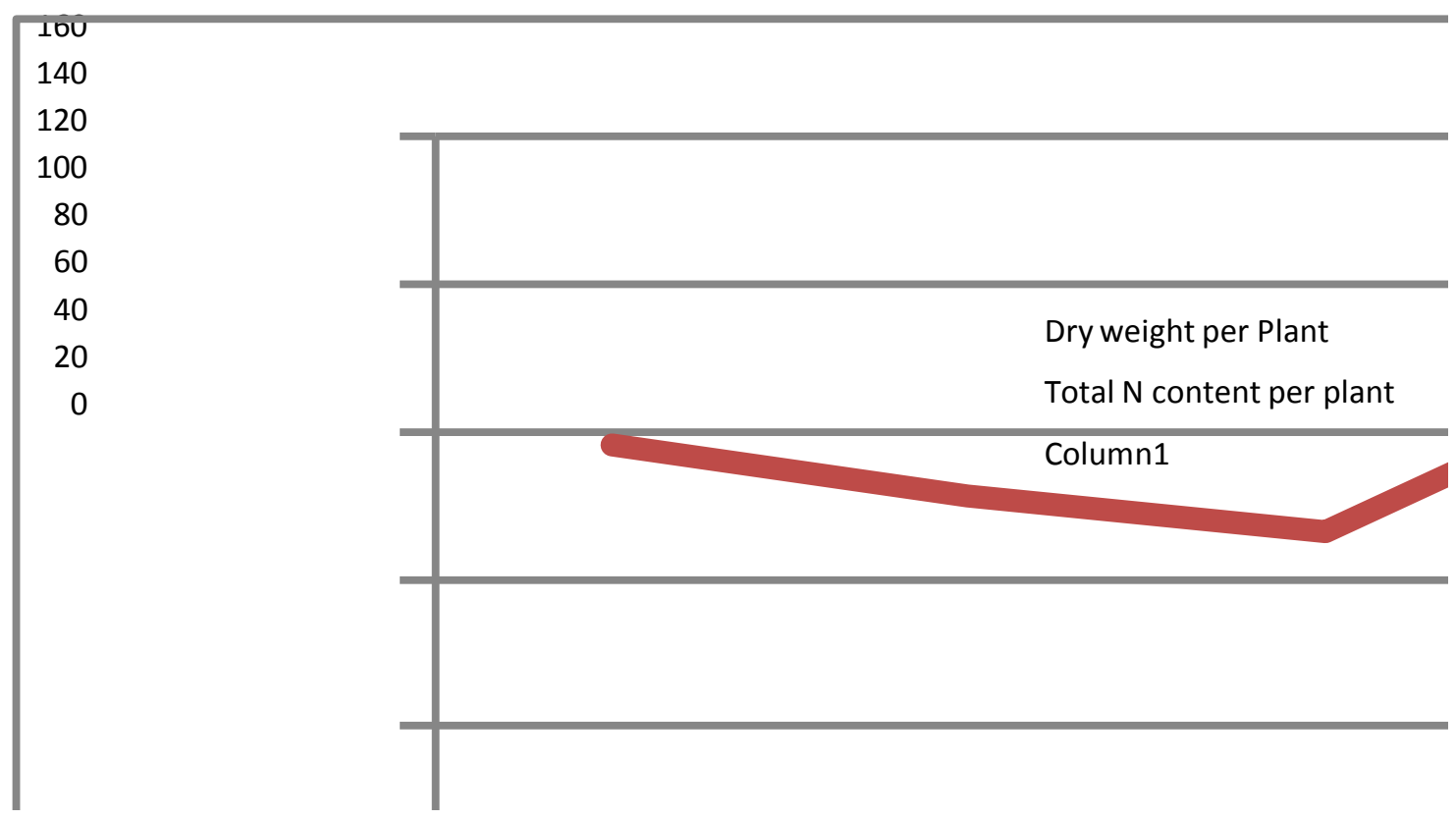

Dry weight and total nitrogen content of plant

The overall effect of fungicides application along with Rhizobium on the dry weight and total nitrogen content of groundnut plant are presented in table 8 . It is clear from the data that, none of the fungicidal seed treatments influenced an adverse effect on the dry weight and total nitrogen content per plant. Vitavax 
was found highly compatible with Rhizobium. When dry weight and total $\mathrm{N}$ content were considered as the parameters, Thiram and ceresin reduced the dry weight and nitrogen content, but the reduction did not achieve the level of significance and it was as per with the Rhizobium alone treatment. Seasonal variations were observed as treatments such as Bavistin + Thiram, which produced significant increase in the dry weight and total $\mathrm{N}$ content per plant was as per with Rhizobium alone.

Five Fungicides viz., Thiram, Cerasan, Bavistin SD, Bavistin WP, and Vitavax, and there combinations were tested as seed dressers along with Rhizobium in a pot culture experiment. The results of the experiment are summarized below:

1) Cerasan was detrimental to Rhizobium as it reduced the nitrogen fixing ability and yield.

2) Vitavax was highly compatible with Rhizobium as none of the $\mathrm{N}$ - fixing traits were adversely affected by the treatment. Instead, Vitavax improved the $\mathrm{N}$ - fixing ability of Rhizobium and enhanced yields.

3) Bavistin WP, Bavistin SD, Thiram and the combination of Bavistin WP + Thiram and Vitavax + Thiram was compatible with Rhizobium inoculation and none of them brought about significant detrimental alternations in the $\mathrm{N}$ - fixing ability of rhizobia.

4) Seasonal variations were apparent on the effect of Bavistin and Thiram but not in
Vitavax and cerasan, some of these chemicals were more compatible.

Afield experiment was conducted using randomized block design were Rhizobium alone with six fungicidal treatments were examined for their influence on $\mathrm{N}$ - Fixation and pod yield. Ceresin produced adverse effect on the introduced Rhizobium as the nitrogen fixing parameters and pod yield were substantially declined in this treatment. On the contrary vitavax was found highly compatible as it improved the N- Fixing parameters and pod yield. Rest of the fungicides and their combinations were compatible as none of them adversely affected the nitrogen fixation by Rhizobium.

\section{References}

Anonymous. 1985. Rhizobia may alter the efficiency of seed dressing fungicides, Plant Pathol. Courier, 3(1): 2.

Asghari, M.R. 1985. Pathogencity and fungicidal sensitivity of Aspergillus niger and Sclerotium rolfsii in groundnut M.Sc. Dissertation, Submitted M. A. U. Parbhani.

Balaraman, K. And Prasad, N.M. 1973. Influence of wet ceresin seed treatment on nitrogen fixation by Rhizobium in groundnut. Pesticides, 7(1): 11.

Dalela, G.G. and Ladha, P.C. 1976. Effect of seed dressing fungicides on nodulation and yield groundnut crop inoculated with Rhizobium strains. Phytopathmed., 15(2/3): 127-128.

Furtode, A. 1977. Effect of systemic fungicides on soil microbial population and nodulation by Rhizobium spp. College of Agriculture, Dharwar, Thesis Abstract, 3(4): 286-287.

\section{How to cite this article:}

Jinturkar, B.P. 2017. Compatibility between Groundnut Rhizobium and Seed Dressing Fungicide. Int.J.Curr.Microbiol.App.Sci. 6(5): 1067-1075.

doi: https://doi.org/10.20546/ijcmas.2017.605.116 